\title{
STRUCTURAL ECONOMIC CHANGES - DIFFERENCES IN THE APPROACHES
}

\author{
S. Totev* \\ Economic Research Institute, Bulgarian Academy of Sciences, Sofia, Bulgaria
}

\begin{abstract}
The ability of an economy to adapt to changing economic conditions through the implementation of structural changes is linked to its ability to effectively generate economic growth. The need to know the intensity and direction of favourable structural changes is of key importance for achieving their high efficiency. In the article, a critical analysis of the different structural economic policies is made, taking into account the consequences of implementing the ones that are not in line with the real economic circumstances. Examples of so-called premature deindustrialisation as a result of inadequate structural policy are also considered. In conclusion, the vision of the role of the state in the conduct of a structural economic policy to achieve favourable economic results is presented.
\end{abstract}

Key words: Economic efficiency, Comparative advantages, Structural policy, Premature deindustrialisation

\section{INTRODUCTION}

Favourable economic development is associated with changes in the industrial structure, implemented in branches and sectors, for which it is inherent higher productivity of labour. The economic factors that determine the intensity and direction of structural changes for each country in a particular period are specific features that changes over time.

In practice, these "features" determine the comparative advantages of the countries and respectively their "optimal" economic structures -- in order to "improve" the industrial structure of a country or region, it is first of all necessary to create the necessary prerequisites for such improvement. Then structural changes can be expected to be as effective as possible. The ability of an economy to adapt to the modifying economic conditions through structural changes is linked to the ability of this economy to accomplish effective economic growth. In its development, the structural approaches to

\footnotetext{
*Correspondence to: Professor, Dr. Stoyan Anastassov Totev, Economic Research Institute, BAS, 3, Aksakov Street, 1040-Sofia, P.O. Box 788 Bulgaria, Tel: (+3592)8104046, Fax: (+3592)9882108, E-Mail: stotev@yahoo.com
}

economic research passes through three approaches (stages).

\section{DIFFERENCES IN THE APPROACHES}

The first, recommends that the governments of developing countries have to disregard the real comparative advantages of their economy and overcome "market failures", through direct administrative measures, notably market distortion of price formation and protectionist policy - the goal is to reach economically efficient structures. Practice shows that the attempt to pursue such a policy leads to a deterioration in the economic situation.

The other, so to speak, the opposite approach to the first is that of neo-liberalism, the presumption is that the fully liberalized market will lead to desirable development in the direction of achieving an economic structure corresponding to one in a developed economy. Such "shock therapy," in countries with weaker economies, which is trying to implement simultaneously and immediately, liberalization and neoliberal privatization policy is possible and more likely not to work.

Against the backdrop of these two structural approaches, the neo-structuralism "new structural economy" seeks to combine them by 
supposing the market to serve as the main mechanism for resource allocation, with economic policy having to play only the role of a tool that makes it easier for firms to switch to productions that is compatible with the comparative advantages of the economy and, at the same time, with higher labour productivity.

Fundamental to the "New Structural Economy" is to focus on the fact that even if economic policy is geared towards the "right" growth industries (those with comparative advantages), companies will not be competitive if they do not have the technical capacity, and suitably developed "soft" and "hard" infrastructure.

The "hard" infrastructure refers to the construction of large physical networks necessary for the functioning of a modern industrial nation. Examples of "hard" infrastructures are transport systems, telecommunication systems, energy supply, sewage, etc. The "soft" infrastructure refers to all institutions that are necessary to maintain a country's high economic and social standards the financial system, education system, health care system, management system, judicial system, and so on.

It is very important that the state has the capacity to provide these infrastructures, and as for the "hard" infrastructure it all depends on investment capacity, the changes in "soft" infrastructure are related to the work of the institutions what imply the existence of real public attitudes, which to allow this to be achieved.

\section{THE ROLE OF THE STATE}

\section{"Even the best intentions cannot} overcome the force of the institutional inertness. " Lyles, J. [1]

The recent financial and economic crisis has resumed the classical debate to what extent governments can and should stimulate economic growth, debate that is indirectly associated with the different structural approaches in the economy and the role of the state.

The experience shows that the probability of making mistakes in conducting these policies is much greater than to achieve the right choices. One of the most common reasons for this is the not taking into account the need for a prepared workforce to be included in the selected activities requiring specific experience and education.

In practice, these policies in the countries with weaker economies that are aimed at stimulating economic growth most often turn out to be unrealized for two reasons - they are too ambitious in the direction on industrial modernization (they are unrealistic) or the politicians are unable to determine what is best for the economy under the specific economic conditions at that particular moment.

Also, any "new" economic policy faces the challenge of avoiding the traps of current and previous clichés of what industrial policy should be, clichés that are little or much in the minds of politicians and economists. One such cliche drafted by the EU administration is the need for each country in the Union to tie its development to the greatest extent with the socalled "Knowledge based development" and to provide "Knowledge based economic policy". These wishes are hard to be realized because they do not meet the economic capabilities of most EU member states and remain without coverage. Nonetheless, they lay down, (at least in the intentions) of the economic policies of the weaker EU countries economies.

That in practice leads to declaring official economic policies, which are not feasible, respectively to the lack of opportunity for their actual conducting. For example, the widelyadvertised Lisbon Strategy for EU Development for the years 2000 - 2010 was intended to make EU "the most competitive and dynamic knowledge-based economy in the world capable of sustainable economic growth with more and better jobs and significant social cohesion". Anyway now, no one discusses the complete failure of this intention, but the accepted phraseology continues to be found in EU documents and of course in the Bulgarian ones.

Another example of deeply rooted misconceptions about what economic policy can be achieved is the widespread nostalgic perceptions of how Bulgaria has built during the period of plan economy a prosperous industry, and now it is only a question of providing same "right" and purposeful economic policy in order to recover the economy again.

Without get into debates, to what extent is this true, these beliefs, true or false, should not in any way affect current economic policy 
because Bulgaria faces entirely different prerequisites and economic conditions market economy, demographic crisis, free labour movement that does not encourages skilled workers to stay in the country, impossibility to attract investments in high efficiency industries and many other specific for Bulgaria economic circumstances.

Most leading economists consider and recommend that the role of the state should be limited to:

- $\quad$ seeking to effectively improve the "hard" and "soft" infrastructure, to facilitate the industrial development of the economy;

- $\quad$ providing information on the comparative advantages of certain proceedings and industries;

- coordinating investment in related industries with respect to the comparative advantages;

- $\quad$ subsidizing activities with external factors - stimulating the development of certain industries by attracting foreign direct investments.

\section{PREMATEUR DEINDUSTRIALISATION}

Numerous theoretical analyses, as well as economic reality, show that industrialisation is an imperative for successful economic development. It produces favourable structural changes, especially in countries with weaker economies. These countries face the question of whether their future development is on a path of continuing industrialization or for one reason or another, they are facing with an inevitable deindustrialisation [2]. UNIDO [3] defines deindustrialisation as "a long-term decline in industrial production compared to other sectors of the economy.

As developed economies reach a level where a process of reducing the relative share of industry at the expense of services occurs, sometimes such processes occur with higher intensity in developing countries. Such sectoral change may be premature for an economy that has not reached the maturity of developed economies. These cases the economists determine as premature deindustrialisation, mean that structural changes in these countries lead to an increase in services at the expense of the industry, without having reached the level of industrialisation previously required, [4].

Structural changes as a result of intense
deindustrialisation, when industrial
"maturity" is not reached, lead to the

formation of an ineffective economic structure and impede economic development as a whole.

Rowthorn and Wells, [5] define three alternative hypotheses to explain the occurrence of deindustrialisation processes:

- the maturity hypothesis according to which once a certain volume of GDP per capita has been reached, the proportion of manufacturing will inevitably begin to diminish at the expense of an increase in the share of services;

- the hypothesis of specific specialization, according to which the patterns of trade and the specificities of an economy shapes the structure of the produced product and the employment where the share of the industry is not high as in most developed countries, (For example, the low share of manufacturing in Malta, Cyprus and Greece is the result of well-developed tourism and related services, in the case of Switzerland, Luxembourg and Hong Kong, it is the result of highly developed financial services).

- the hypothesis of unsuccessful industrialisation when the failure of the manufacturing industry is due to the structural "weakness" of the economy that makes deindustrialisation inevitable.

Different causes and factors determine the development according to the third hypothesis, but the main one is the lack of clear comparative advantages in the manufacturing in the context of globalization (the factor China and other Asian countries). For countries with weak economies, deindustrialization, in effect, eliminates the basic way in which economic growth has been realized - it blocks the main road to economic convergence with developed countries.

\section{BULGARIA AND THE PROCESS OF DEINDUSTRIALISATION AND STRUCTURAL CHANGES} The structure and changes of the industrial sector in Bulgaria are very close to the general levels and trends of the Central and Eastern European countries. It is not observed processes of premature deindustrialisation in the changing of the relative participation of the industry; on the contrary, Bulgaria can be said to be one of the countries that have adapted their industrial production well in the conditions of the last economic crisis - the 
share of GVA has increased compared to that of the employed, as a result of which the relative productivity of labour has also increased.

However, the objective assessment unambiguously shows that at least for the time being, our country has little potential to develop high-tech products. It is very important for the state to have the capacity to do so, and while in terms of "hard" infrastructure it is all about investment capacity, the changes in "soft" infrastructure is related to the work of the institutions and imply the existence of real public attitudes that will allow this to be achieved. In this respect, the expectations for creating such a soft infrastructure environment for Bulgaria are very low, as in Bulgaria the assessment of the institutions' performance has the lowest indicators than those of the EU countries and significantly lower than the world average, [6]. Certain role for that represent and the influence of the so called ,geographical factor".

Such an statement can be find in the the EU Industrial Structure Report [7], when comparing the 1995-1995 Economic Innovation Index (ECI) is noted: "In general, it is expected that countries with low ECI in 1995 will see an increase for the monitored period as a result of a catch-up process. However, some countries (namely Turkey, Greece, Romania and Bulgaria) appear to be deprived of the benefits of globalization and market liberalization."

Obviously, the difficulties faced by these countries are characteristic of these geographical latitudes. For this reason, whenever forecasts and comparisons are made about the Bulgaria's economic potential, it is necessary to bear in mind that for one reason or another thing do not happen in our country in the way it is expected on the basis of comparison with the other countries

\section{ACKNOWLEDGMENT}

This work was supported partially supported by the Bulgarian Ministry of Education and Science

under the National Research Programme "Heal thy Foods for a Strong Bio-Economy and Quality of Life" approved by DCM \# 577 / 17.08.2018".

\section{REFERENCES}

1. Lyles, J., Structuralism: a movement for good governance, Let a Thousand Nation Bloom, Towards a Cambrian Explosion in Government, July 3, 2012.

2. Palma, J., De-industrialisation, 'Premature' De-industrialisation and the Dutch Disease. In: Durlauf, S. and Blume, L. (eds.): The New Palgrave Dictionary of Economics, Second Edition, Basingstoke. 2008.

3. UNIDO, Industrial Development Report 2013. Sustaining Employment Growth: The Role of Manufacturing and Structural Change, Vienna. 2013.

4. Ramaswamy, R. and Rowthorn, R., Deindustrialisation - Its Causes and Implications, International Monetary Fund, September, 1997.

5. Rowthorn, R. and Wells, J., DeIndustrialisation and Foreign Trade. Cambridge University Press.1987.

6. Totev, S., Sariiski, G. and Stoicheva, I., (2016), Comparative assessment of the competitiveness of the Bulgarian economy, Economic Thought, Vol. 4, 2016.

7. EU Industrial Structure Report, Competing in Global Value Chains, European Commission Report, 2013 p. 84. 